\title{
REALITAS LITERASI MEDIA PADA IBU-IBU JAMAAH MAJELIS TAKLIM NURUL HIKMAH, DESA TANJUNG KARANG, CIGALONTANG, TASIKMALAYA, JAWA BARAT
}

\section{DOI: https://doi.org/10.38214/jurnaldawahstidnatsir.v4i01.92}

\author{
Santa Lorita Simamora \\ Santa.lorita@mercubuana.ac.id \\ Universitas Mercu Buana, Indonesia
}

\begin{abstract}
Impressions program broadcast media were more varied, especially the entertainment program demanding society audience should have the ability to screen a wide range of entertainment programs such content. The reality is not so, is not proportional between variety program and the community's ability to filter information which may enter into her mind. This is especially seen in public audiences in rural areas. As stated by Nielsen Media Research that the majority of the audience in Indonesia is a community social economic status $C$ and D, where their ability to seek more entertainment through a private television station. While their ability to sort out the entertainment program content can not be said to be feasible. The Research method used is descriptive qualitative research. Through this research, the researcher tries photographing reality lack the ability of mothers touched Majelis Taklim Nurul Hikmah, Tanjung Karang Village, Cigalontang, Tasikmalaya, West Java during the first month, which is the period of May 29 to June 26, 2018. Additionally depth interviews were conducted that research subjects 30 mothers touched Majelis Taklim Nurul Hikmah. The results of the research findings that the ability of mothers in sorting, filtering content impressions entertainment program is minimal, so with various limitations, the mothers can not provide assistance to the children or their grandchildren when watching television programs, especially the entertainment program.
\end{abstract}

Keywords: Media Literacy, Media Broadcasting

\begin{abstract}
ABSTRAK
Tayangan program media penyiaran yang makin variatif, terutama program hiburan menuntut mayarakat penonton harus memiliki kemampuan dalam
\end{abstract}


menyaring berbagai konten program hiburan tersebut. Realitasnya tidak demikian, tidak berbanding lurus antara variatifnya program dan kemampuan masyarakat menyaring informasi mana yang boleh masuk ke benaknya. Hal ini terutama terlihat pada masyarakat penonton di daerah pedesaan. Seperti yang diutarakan Nielsen Media Riset bahwa mayoritas penonton di Indonesia adalah masyarakat status ekonomi sosial C dan D, di mana kemampuan mereka dalam mencari hiburan lebih banyak melalui stasiun televisi swasta. Sementara kemampuan mereka memilah-milah konten program hiburan belum bisa dikatakan layak. Metode riset yang digunakan peneliti adalah deskriptif kualitatif. Melalui riset ini, peneliti mecoba memotret realitas minimnya kemampuan ibuibu jamah Majelis Taklim Nurul Hikmah, Desa Tanjung Karang, Cigalontang, Tasikmalaya, Jawa Barat selama 1 bulan, yaitu periode 29 Mei-26 Juni 2018. Selain itu dilakukan wawancara mendalam terhadap subyek penelitian yaitu 30 ibu-ibu anggota jamah Majelis Taklim. Hasil penelitian diperoleh temuan bahwa kemampuan ibu-ibu dalam memilah-milah, menyaring konten tayangan program hiburan minim sehingga dengan berbagai keterbatasan yang dimiliki, para ibu tersebut tidak dapat memberikan pendampingan kepada putra-putri atau cucu mereka ketika menonton tayangan program televisi khususnya program hiburan.

Kata Kunci : Literasi Media, Media Penyiaran

\section{PENDAHULUAN}

Televisi saat ini telah berkembang menjadi industri hiburan di Indonesia, dimana orientasi utama dari industri hiburan tersebut adalah uang, sehingga seringkali mengabaikan fungsinya sebagai alat pendidikan bagi masyarakat. Fakta menunjukkan bahwa media tidak dapat disalahkan sepenuhnya, realitasnya mayoritas masyarakat penonton berasal dari status ekonomi sosial C dan D menjadikan media televisi sebagai media hiburan utama akibat keterbatasan ekonomi mereka mencari media hiburan alternative, seperti yang dilakukan masyarakat penonton berstatus ekonomi sosial C dan D yang tinggal di pedesaan.

Tayangan televisi banyak yang tidak sesuai dengan tatanan nilai budaya masyarakat ketimuran, seperti eksploitasi kekerasan dan sensualitas melalui program hiburan seperti film, sinetron dengan alur yang menggambarkan gaya hidup hidup glamour san cerita tidak realistis, musik, dan program hiburan berformat variety show. Bahkan program berita turut menyajikan peristiwa kriminalitas yang mengeksploitasi tampilan sadisme misalnya melalui sajian reka ulang yang menimbulkan kengerian dan menjadi contoh bagi pelaku kriminal lainnya. 
Masyarakat dengan status ekonomi social kelas $\mathrm{C}$ dan $\mathrm{D}$ diasumsikan memiliki tingkat pendidikan rendah dan minim kemampuan dalam menyaring konten media televisi yang layak dikonsumsi. Untuk itu dibutuhkan melaksanakan kegiatan literasi media secara berkesinambungan bagi masyarakat penonton status ekonomi sosial $\mathrm{C}$ dan $\mathrm{D}$ tersebut.

Kegiatan sosialisasi dan membuka kesadaran masyarakat akan literasi media sebenarnya sudah banyak dilakukan di Indonesia, seperti oleh organisasi masyarakat dan lembaga pendidikan, termasuk lembaga pemerintah terkait. Seperti yang dilakukan oleh Masyarakat Peduli Media (MPM) menerapkan pendidikan literasi media dengan melakukan pembinaan terhadap ibu-ibu untuk tidak sekedar paham dan kritis terhadap media namun juga menjadi aktivis literasi media. Program MPM menjadikan ibu-ibu sebagai subjek dalam menjalankan program literasi media.Namun kegiatan sosialisasi tersebut baru menyentuh wilayah perkotaan di pusat pemerintahan, belum merata ke daerah terutama desa atau kampung, nyaris sosialisasi literasi media belum bergema. Terkesan Lembaga pemerintah dan media penyiaran masih setengah hati dalam kegiatan tersebut, terbukti bahwa kegiatan sosialisasi literasi media belum menjadi agenda rutin dan besar dari lembaga pemerintah terkait, yaitu Dekominfo. Gaung kegiatan sosialisasi literasi media belum kuat terdengar, terutama kepada masyarakat status ekonomi sosial C dan D di wilayah daerahdaerah pedesaan. Lembaga pendidikan yang melaksanakan kegiatan sosialisasi literasi media dilakukan lebih banyak melalui kegiatan Pengabdian Masyarakat Lembaga Pendidikan seperti kampus (sebagai penerapan salah satu Tri Dharma Perguruan Tinggi) setiap semester satu kali, itupun dilakukan oleh bidang ilmu terkait dalam ilmu sosial, seperti ilmu komunikasi dan dengan waktu serta fasilitas pendukung seadanya.

Salah satu Desa di wilayah Tasikmalaya, Jawa Barat yang belum tersentuh oleh kegiatan sosialisasi dan pelatihan literasi media ialah Desa Tanjung Karang, Kecamatan Cigalontang, Kabupaten Tasikmalaya, Provinsi Jawa Barat. Dimana masyarakat setempat Desa Tanjungpura mayoritas berprofesi sebagai petani dan buruh tani, dengan tingkat pendidikan mayoritas rendah.

Sejauh ini kegiatan literasi media di Indonesia telah banyak dilakukan oleh berbagai lembaga swadaya masyarakat, perguruan tinggi dan pemerintah melalui instansi terkait, namun belum merata hingga wilayah pedesaan seperti salah satu contohnya adalah Desa Tanjung Karang, Cigalontang, Tasikmalaya, Provinsi Jawa Barat. Literasi media menjadi kebutuhan sebagai upaya gerakan melindungi masyarakat penonton dari pengaruh tidak sehat akibat terpaan siaran televisi yang kurang mendidik terutama bagi ibu-ibu yang merupakan tempat belajarnya anak-anak sebagai generasi penerus masa depan bangsa Indonesia. 
Jika pihak ibu dibekali kemampuan literasi maka ia akan dapat melakukan pendampingan ketika anak-anak menonton televisi. Ibu yang memiliki literasi media mampu membedakan acara yang mendidik dan tidak mendidik. Namun bagaimana sebaliknya bila ibu tidak memiliki literasi media, ibu tidak dapat membedakan mana acara yang mendidik dan tidak mendidik, sehingga tidak dapat melakukan pendampingan kepada putra-putrinya saat menonton televisi.

Hasil penelitian salah satu Lembaga Swadaya Masyarakat yang peduli literasi media bagi masyarakat yakni Masyarakat Peduli Media (MPM) 2013, menyatakan bahwa sebanyak 50,0\% ibu rumah tangga selalu dan sering menonton TV berkisar 5-8 jam sehari dan sebanyak 25,0\% menonton TV di atas 8 jam sehari. Data ini menunjukkan bahwa waktu yang digunakan para ibu cukup lama di depan televisi. Bagaimana bila para ibu tersebut tidak melek media alias tidak memiliki kemampuan dalam memilah, menyaring konten media mana yang mendidik dan tidak mendidik?

Salah satu wilayah yang belum terjamah kegiatan sosialisasi literasi media tersebut, sebuah desa yaitu Desa Tanjung Karang, Cigalontang, Kabupaten Tasikmalaya, Jawa barat. Ibu-ibu anggota Majelis Taklim Nurul Hikmah, Desa Tanjung Karang, Cigalontang, Tasikmalaya sama sekali asing dengan istilah literasi media atau melek media. Mendengarnya saja belum pernah apalagi mengenal dan memahami apa itu literasi media. Bagaimana memilah-milah tontonan layak lihat buat putra-putri atau cucu mereka, pun tidak mereka pahami.

Maka dalam makalah ini dirumuskan satu masalah terkait fenomena di Desa Tanjung Karang, Cigalontang, Tasikmalaya, Jawa Barat, yaitu: Bagaimana literasi Media para ibu-ibu anggota Majelis Taklim Nurul Hikmah Desa Tanjung Karang, Cigalontang, Tasikmalaya, Jawa Barat?

Tujuan yang ingin dicapai di awa riset saat itu yaitu mengetahui dan akhirnya dapat mendeskripsikan realitas kondisi literasi media para ibu-ibu anggota Majelis Taklim Nurul Hikmah Desa Tanjung Karang, Cigalontang, Tasikmalaya, Jawa Barat.

\section{Konsep dan Pengertian Literasi Media}

Literasi media berasal dari bahasa Inggris yaitu media literacy terdiri dari dua suku kata media berarti media tempat pertukaran pesan dannliteracy berarti melek, kemudian dikenal dalam istilah literasi media. Dalam hal ini literasi media merujuk kemampuan khalayak yang melek terhadap media dan pesan media massa dalam konteks komunikasi massa (Tambaruka, 2013: 7). Literasi media merupakan sebuah konsep tentang cara-cara masyarakat mempertanyakan apa yang ditonton, dicermati, dibaca dan diproduksi dari media. Dengan demikian masyarakat dapat melakukan kontrol terhadap isi media secara kritis dan cerdas 
sehingga dapat mendeteksi adanya propaganda, kepentingan tertentu atau bias dalam sebuah tayangan.

Potter (2001:4) dalam bukunya Media Literacy mendefinisikan literasi media sebagai perspektif di mana individu secara aktif dapat merespon media dan menafsirkan makna pesan yang diterima. Keaktifan individu dalam bermedia dipengaruhi oleh pengetahuan masing-masing individu yang diperoleh baik melalui media maupun lingkungannya. Yang dimaksud dengan penggunaan aktif bermedia di sini adalah adanya kesadaran individu terhadap pesan yang disampaikan oleh media dan interaksi yang seharusnya dibangun dengan media.

Berkaitan dengan persoalan ini, Potter mengungkapkan: "Media Literacy is a set of perspectives that we actively use to expose ourselves to the media to interpret the meaning of the messages we encounter. We build our perspectives from knowledge structures. To build our knowledge structures, we need tools and raw material. These tools are our skills. The raw material is information from the media and from the real world. Active use means that we are aware of the messages and are consciously interacting with them" (Potter, 2001:4).

Dari paparan tersebut menunjukkan bahwa dalam membangun kemampuan literasi media Potter (2005: 34) membagi struktur pengetahuan ke dalam tiga kategori guna mendukung perspektif literasi media. Pertama, pengetahuan tentang isi atau konten media. Kedua, pengetahuan tentang industri media. Ketiga, pengetahuan tentang efek media. Dari ketiga struktur pengetahuan yang ditawarkan Potter, dapat diambil sebuah konklusi konkret bahwa kemampuan literasi media dibangun dari pemikiran kritis atas setiap konten yang disajikan media. Artinya, audiens harus mampu menganalisa dan menginterpretasi isi pesan, mengetahui proses industrialisasi media hingga pada dampak yang ditimbulkan oleh media. Ketika audiens berhadapan dengan pesan media, maka audiens akan membandingkan informasi yang berada dalam pesan tersebut dengan informasi yang ada dalam struktur pengetahuannya. Menurut Potter (2001:78), ketika audies tidak mempunyai struktur pengetahuan untuk beberapa informasi yang baru, maka audiens tidak dapat melakukan penilaian terhadap informasi tersebut. Hal ini berarti bahwa stuktur pengetahuan yang dimiliki akan menentukan bagaimana harus menyikapi pesan media. Dengan kata lain, struktur pengetahuan yang dimiliki akan menentukan tingkat kemampuan (skill) dalam menghadapi pesan media skill dan struktur pengetahuan mempunyai hubungan yang erat satu dengan yang lain guna melihat seberapa tinggi tingkat literasi seseorang ketika berhadapan dengan media. Agar audiens memiliki tingkat literasi media yang baik, maka audiens harus memiliki struktur pengetahuan yang memadai tentang media.

Art Silverblatt (dalam Baran 2011: 32), mengemukakan struktur pengetahuan literasi media yaitu pertama, semua media merupakan hasil konstruksi. Media tidak menampilkan reflex sederhana dari realitas eksternal. Ini adalah konsep dasar yang perlu ditekankan, bahwa apa yang disampaikan media tidak berdasarkan realitas yang sebenarnya. Pemberitaan media merupakan hasil konstruksi, dan literasi media berupaya untuk membangun kembali konstruksi 
tersebut. Kedua, media membangun realitas. Pemahaman kita mengenai apa yang sedang terjadi di sekitar kita merupakan hasil dari konstruksi media. Media berusaha membangun pemikiran kita berdasarkan apa yang diberitakan. Ketiga, audiens dapat menyesuaikan makna terhadap apa yang ditampilkan oleh media. Media banyak menyuguhkan berbagai macam informasi namun masyarakat juga dapat menyesuaikan makna dari pesan di media berdasarkan pada faktor individu, seperti kebutuhan personal, latar belakang keluarga dan kebudayaan, pendirian moral, dan sebagainya. Pemaknaan sangat tergantung pada faktor individu dan bersifat personal. Keempat, pesan dalam media memiliki implikasi komersial. Hampir semua produk media merupakan bisnis dan berorientasi pada keuntungan. Media di masa kini masih sering dikuasai oleh kepentingan pihak lain baik media itu sendiri atau pun informasi di dalamnya. Masing-masing media memiliki pemegang yang mengatur serta mengendalikan jalannya media tersebut. Oleh karena itu kita harus sadar bahwa media bisa dikontrol oleh segelintir orang. Dalam hal ini literasi media mencoba membangun kesadaran terkait hal itu sehingga tercipta sebuah kontrol atas apa yang ditonton, dibaca, dan didengar melalui media. Kelima, pesan dalam media mengandung unsurunsur ideologi dan nilai-nilai tertentu. Misalnya melalui iklan, media berusaha mengkonstruksikan bahwa cantik itu tinggi, putih dan langsing. Media selalu menghadirkan pesan-pesan ideologis yang berbalut isu seperti pencitraan sosok ideal seorang wanita, gaya hidup yang baik, kebaikan dalam konsumerisme, dan sebagainya. Keenam, pesan dalam media memiliki implikasi terhadap aspek sosial dan politik. Media memiliki pengaruh yang sangat kuat terhadap proses politik dan membentuk perubahan sosial. Media juga punya kekuatan yang bisa mengarahkan opini pada isu-isu tertentu. Misalnya menggiring opini publik pada kandidat presiden atau melibatkan partisipasi publik pada isu seperti ikut terlibat dalam menanggulangi HIV/AIDS atau gerakan kaum feminis. Ketujuh, bentuk dan isi pesan media memiliki hubungan yang dekat. Setiap media memiliki cara masing-masing dalam mengemas sebuah peristiwa. Sebuah peristiwa yang dilaporkan bisa saja sama, tapi dapat menimbulkan kesan yang berbeda bagi audiens. Kedelapan, setiap media memiliki bentuk estetika yang unik. Media satu dengan media yang lain tentu memiliki karakter yang berbeda. Televisi memiliki karakter audiovisual, dan ini berbeda dengan radio yang memiliki karakter audio saja. Perbedaan ini pada akhirnya akan menghasilkan nilai estetis yang berbeda antar media.

Dari apa yang telah dipaparkan dapat dipahami pengertian literasi media dan arti pentingnya dalam membantu membangun kesadaran bahwa media tidak bersifat netral, selalu ada unsure kepemilikan, idieologi institusi, komersialisasi dan kepentingan di dalam sebuah produk media. Kesadaran seperti ini juga menunjukkan bahwa audiens memiliki otonominya sendiri dan memiliki power yang lebih besar dari media. Dan masyarakat harus memiliki sikap terhadap media sebelum media berbalik menyetir kehidupan masyarakat. 
Delapan konsep kunci tersebut menjadi awal dari perkembangan keterampilan (skill) literasi media.

Berdasarkan uraian di atas dapat diketahui bahwa skill dan struktur pengetahuan berkaitan erat satu dengan yang lain guna melihat seberapa tinggi tingkat literasi seseorang ketika berhadapan dengan media. Semakin kuat struktur pengetahuan, maka tingkat literasi terhadap media juga akan semakin tinggi. Sebaliknya semakin rendah tingkat literasi media seseorang, maka semakin sedikit atau dangkal pesan yang didapatkannya. Seseorang yang tingkat literasi medianya rendah akan sulit mengenali ketidakuratan pesan, keberpihakan media, memahami kontroversi, mengapresiasi ironi atau satire. Bahkan kemungkinan besar orang tersebut akan dengan mudah mempercayai dan menerima makna-makna yang disampaikan media tanpa berupaya mengkritisinya. Dengan literasi media diharapkan dapat meningkatkan kemampuan individu dalam mengakses, menganalisis, mengevaluasi, dan menyusun informasi dalam variasi format media (Potter, 2001: 261).

Uraian teori dan konsep di atas menjadi landasan berpikir peneliti membahas Minim literasi media pada ibu-ibu anggota Majelis Taklim Nurul Hikmah Desa Tanjung Karang, Cigalontang, Tasikmalaya, Jawa Barat.

Penelitian dilakukan periode 29 Mei-26 Juni 2018, dilaksanakan di Desa Tanjung Karang, Cigalontang, Tasikmalaya, Jawa Barat. Pemilihan lokasi tersebut karena wilayah Desa Tanjung Karang belum pernah dilakukan kegiatan sosialisasi literasi media. Penelitian menggunakan pendekatan kualitatif dengan metode deskriptif kualitatif, mengkaji terkait kondisi realitas ibu-ibu anggota Majelis Taklim Nurul Hikmah, Desa Tanjung Karang, Cigalontang, Tasikmalaya tidak memiliki literasi media alias tidak melek media. Prosedur dalam penelitian ini yakni mengumpulkan data secara langsung melalui wawancara mendalam , observasi dan studi pustaka. Teknik wawancara mendalam merupakan teknik pengambilan data yang paling utama yang difokuskan pada informasi tentang kemampuan ibu-ibu anggota Majelis Taklim Nurul Hikmah Desa Tanjung Karang dalam membedakan acara mendidik dan tidak mendidik.

Mengenai tahapan dalam proses wawancara yang dilakukan meliputi:

a) peneliti memberikan informasi secara singkat mengenai tujuan penelitian,

b) peneliti melakukan proses wawancara dengan menanyai langsung kepada informan berkaitan dengan penelitian. Selanjutnya agar proses wawancara berjalan dengan baik, peneliti menggunakan skrip dengan topik yang rinci sebagai panduan wawancara. Peneliti juga dapat menggunakan alat bantu seperti rekaman, dan catatan.

Prosedur berikutnya yakni proses penulisan untuk mengubah komunikasi lisan ke dalam teks tertulis setelah proses wawancara selesai dalam bentuk transkrip. Setelah itu, prosedur yang terakhir yakni menganalisis hasil wawancara dengan langkah kode, mengkategorikan, memadatkan dan menafsirkan data. Hal ini merupakan proses untuk memahami data dan memperoleh makna dari penjelasan transkrip wawancara. Dalam melakukan 
kode dan kategori data dapat dilakukan dengan menyingkat data dengan menyingkat pernyataan panjang dari hasil wawancara menjadi beberapa kata kunci dan menafsirkan data serta menghubungkan makna dengan konteks kerangka teoritis. (Spradley, 2006: 132). Disamping wawancara juga dilakukan observasi sebagai data pendukung dalam penelitian. Teknik observasi adalah teknik dimana peneliti mengamati langsung subjek yang diteliti. Dalam proses pengumpulan data selain dilakukan melalui studi pustaka, wawancara dan dokumentasi peneliti juga akan mengadakan kunjungan lapangan untuk melakukan pengamatan langsung terhadap aktivitas-aktivitas subjek penelitian dalam aktivitas menonton televisi.

Informan sekaligus subjek penelitian yaitu tiga puluh ibu-ibu anggota Majelis Taklim Nurul Hikmah Desa Tanjung Karang yang umumnya berpendidikan rendah dan menjadi petani atau buruh tani. Informan atau Subjek penelitian memberikan informasi tentang situasi dan kondisi latar penelitian. Informan dalam penelitian ini ditentukan dengan teknik purposive yakni penentuan informan dengan menetapkan kriteria atau pertimbangan tertentu. Kriteria yang menjadi informan dalam penelitian ini meliputi: a) ibuibu anggota Majelis Taklim Nurul Hikmah Desa Tanjung Karang, Cigalontang, Tasikmalaya, Jawa Barat. b) ibu-ibu anggota Majelis Taklim Nurul Hikmah yang berprofesi sebagai buruh tani atau petani. c) ibu-ibu anggota Majelis Taklim Nurul Hikmah yang memiliki anak yang berusia dibawah 12 tahun, c) ibu-ibu anggota Majelis Taklim Nurul Hikmah yang memiliki TV. Berdasarkan kriteria tersebut, maka informan dalam penelitian ini sebanyak 10 orang dari 30 peserta kegiatan sosialisasi literasi media penyiaran.

\section{HASIL DAN DISKUSI}

Ibu-ibu anggota Majelis taklim Nurul Hikmah merupakan merupakan pilar keluarga. Idealnya pilar-pilar rumah tangga harus kokoh, sehingga rumah tangga akan menjadi stabil dan mampu melahirkan generasi yang tangguh dan sukses. Tantangan generasi milenial saat ini adalah kuatnya pengaruh media penyiran yang menawarkan berbagai informasi Dampak negatifnya adalah khalayak menjadi kecanduan dan dihipnotis oleh berbagai konten program yang membius. Oleh sebab itu, iterasi media menjadi sangat urgen terutama bagi ibu-ibu rumah tangga di pedesaan dalam mendidik anak-anaknya. Nara sumber atau sepuluh informan penelitian ini adalah ibu-ibu rumah tangga di Desa tanjung Karang, Cigalontang, Tasikmalaya.

Selain menjadi ibu Rumah tangga Desa Tanjung Karang umumnya para ibu membantu suami mencari nafkah menjadi kuli sawah juragan sawah atau kebun di desa mereka hingga tengah hari. Mereka juga aktif sebagai anggota pengajian majelis Taklim Nurul Hikmah di Desa tanjung Karang. 
Hasil riset menunjukkan bahwa masih banyak ibu-ibu rumah tangga di Desa Tanjung Karang belum mengerti arti penting litrasi media. Hasil wawancara kepada semua nara sumber tersebut menampakkan mereka belum mengetahui apa itu literasi media. Semua informan penelitian berasal dari status ekonomi sosial kalangan ke bawah. Mayoritas dari keluarga kurang mampu dengan pendidikan rendah (SD dan SMP). Kondisi ini yang membuat para ibu tidak memiliki kemampuan atau sulit memahami media terutama informasi-informasi atau berita-berita terkini. Menurut Basri dkk (2019 kemiskinan yang bersumber dari ketidakberdayaan secara ekonomi akibat krisis, masih merupakan penyebab utama munculnya permasalahan sosial lain seperti rendahnya kemampuan literasi media. Dengan kata lain bahwa pendidikan berpengaruh terhadap kepahaman membaca informasi media

Ibu-ibu rumah tangga anggota Majelis Taklim Nurul Hikmah Desa Tanjung Karang, Cigalontang, Tasikmalaya tidak memahami apa yang dimaksud dengan literasi media. Idealnya peran orang tua khususnya ibu sangat diperlukan paham literasi media mengingat besarnya pengaruh media terhadap perilaku anak. Sebagaimana dikemukakan Potter bahwa terdapat tiga struktur pengetahuan yang paling penting dan bermanfaat untuk membangun perspektif literasi media seorang audiens media massa termasuk. Ketiga struktur pengetahuan tersebut yaitu struktur pengetahuan isi media, industri media dan efek media. Struktur pengetahuan isi media merupakan pengetahuan mengenai pesan media, struktur pengetahuan industri media merupakan perkembangan industri media massa seperti asal-usul media dan basis ekonomi, sedangkan struktur pengetahuan efek media merupakan pengetahuan yang berkaitan dengan efek dari media massa. Realitasnya ibu-ibu anggota Majelis Taklim Nurul Hikmah minim memiliki struktur pengetahuan seperti yang dinyatakan Potter. Minimnya struktur pengetahuan ibu-ibu anggota Majelis Taklim Nurul Hikmah diakibatkan pengetahuan terbatas dan belum pernah mendapatkan sosialisasi tentang literasi dari phak manapun yang bertanggung jawab memberikan sosialisasi literasi media.

Fakta di lapangan menunjukkan bahwa kesadaran ibu mendampingi dan mengawasi anak sangatlah kurang. Dengan keterbatasan pengetahuan ibu akan literasi media membuatnya jarang sekali mendampingi anak dalam menonton TV, bahkan ibu kurang memberi batasan tertentu pada anak dalam menonton TV. Hal ini terkesan membuat anak lebih sering menghabiskan waktu luangnya untuk menonton TV tanpa pendampingan ibu. Terbuka 
peluang bagi anak belajar kekerasan, seks, dan contoh buruk lain melalui tayangan hiburan di televisi.

Ibu-ibu anggota majelis taklim Nurul Hikmah Desa Tanjung Karang Cigalontang, Tasikmalaya sebelum diberikan pencerahan literasi media, masih berada pada suasana boleh disebut buta media penyiaran, hanya paham menonton TV menjadi sumber hiburan dan pengisi waktu tanpa tahu dampak yang ditimbulkan, belum bisa memilah dan memilih informasi yang berkualitas berdampak positif bagi keluarga. Ibu-ibu di lingkungan Desa Tanjung Karang diuntungkan dengan adanya aktivitas pengajian Majelis Taklim yang mereka ikuti. Dengan demikian ada aktivitas positif bagi ibuibu tersebut, tidak hanya menonton sinetron dan tayangan musik dangdut. Namun sayangnya kontrol penggunaan media televisi bagi keluarga masih sangat minim, sehingga anak bebas menonton tayangan televisi tanpa pengawasan atau pendampingan berarti dari ibu. Barulah setelah peneliti dan tim memberikan sosialisasi serta pelatihan literasi media, ibu-ibu informan tersebut menjadi paham arti penting literasi media khususnya bagi keluarga mereka. Selanjutnya ibu-ibu tersebut dilatih menjadi agen-agen pembaharuan literasi media di lingkungan mereka.

Pemahaman literasi media atau melek media secara sederhana adalah bagaimana khalayak mampu memilih atau menyaring isi pesan yang disampaikan oleh media. Khalayak mampu membedakan mana yang dianggap penting atau baik dan mana yang dianggap buruk. Pada dataran ini khalayak sudah semakin cerdas, aktif dan kritis. Bahkan khalayak tidak begitu saja mempercayai pesan yang disampaikan oleh media. Untuk itulah dibutuhkan adanya media edukasi dalam konteks literasi media. Wirodono dalam Rejeki (2010:67) mengemukakan tiga kategori khalayak yang rentan terhadap pengaruh buruk media, yakni anak-anak, remaja, dan kaum ibu.

Seks dan mistis menjadi kekhawatiran para ibu-ibu pada remaja, tayangan sinetron dengan tema remaja cenderung mengeksploitasi kehidupan remaja dari satu sisi. Keadaan ini menyebabkan remaja tidak bisa mempelajari realitas yang sesungguhnya. Bagi ibu-ibu pengaruh buruk televisi lebih pada membangun perilaku konsumtif. Mereka merupakan sasaran potensial iklan. Komoditas ini dikemas dalam bentuk tayangan sinetron, infotainment, tayangan kuliner dan sebagainya (Wirodono dalam Rejeki, 2010:69). 


\section{KESIMPULAN}

Berdasarkan pembahasan hasil penelitian dapat diambil kesimpulan, yakni: Pertama, umumnya ibu-ibu anggota majelis Taklim Nurul Hikmah Desa Tanjung Karang, Cigalontang, tasikmalaya tidak memiliki kemampuan memilah atau memilih konten media. Kedua, keterbatasan literasi media para infoman pengaruh pendidikan rendah dan minimnya pengetahuan umum sebagai ibu rumah tangga yang hidup di desa. Ketiga, mayoritas para informan tidak mengetahui akibat yang dapat ditimbulkan dan konten media berbau kekerasan dan seks.

\section{DAFTAR PUSTAKA}

Apriadi Tamburaka. 2013. Literasi Media: Cerdas bermedia khalayak media massa. Jakarta: Rajawali Pers.

Baran, Stanley and Dennis K Davis. 2000. Mass communication theory. Wadsworth: Canada.

Berger, Charles R., and Chafee, StevenH., 2010, The Handbook of Comunication Science, Sage Publication, Newbury Park London,

Denzin, Norman K dan Lincoln, Yvonna. 1994. Handbook of Qualitative Research. London : Sage Publications

Guntarto, B. 2007. Pendidikan Media - Buku Pegangan Untuk Guru Sekolah Dasar. Jakarta: Yayasan Pengembangan Media Anak dan UNICEF.

Littlejohn, Stephen W. 1999. Theories of Human Communication. sixth edition. California : Wadsworth Publishing Company.

Potter, W. James. 2004. Theory of Media Literacy: A Cognitive Approach. London:Sage.

Potter, W. James. 2005. Media Literacy. Third Edition. London: Sage.

Potter, W. James. "Media Literacy." 21st Century Communication: A Reference Handbook. 2009. SAGE Publications. 
McLuhan, Marshall, 2003, Understanding Media, Routledge, London and Newyork.

Moleong, Lexy J. 2006, Metode Penelitian Kualitratif. PT Remaja Rosdakarya:Bandung.

Neuman, W Lawrence. 2000. Social Research Methods : Qualitative and Quantitative Approaches. fourth edition. Boston: Allyn and Bacon.

Silverblatt, Art. 1995. Media Literacy: Keys to Interpreting Media Messages. London: Praeger.

Sasangka dan darmanto. 2010, Ketika Ibu Rumah Tangga Membaca Televisi. Tifa Yogyakarta.

Sendjaya, Sasa Djuarsa, Dkk, 1993, Pengantar Komunkasi, Universitas Terbuka, Jakarta.

Soemandoyo, Priyo. ND. Wacana Gender dan Layar Televisi: Studi Perempuan dalam Pemberitaan Televisi. Ford Foundation dan LP3Y: Yogyakarta.

Wiratmojo, 2010, Ketika Ibu Rumah Tangga Membaca televisi. Tifa :Yogyakarta. 